\title{
The roles of sphingosine kinase 1 and 2 in regulating the Warburg effect in prostate cancer cells
}

\author{
David G. Watson, Francesca Tonelli, Manal Al Osaimi, Leon Williamson, Edmond Chan, \\ Irina Gorshkova/", Evgeny Berdyshev"/, Robert Bittman', Nigel J Pyne, and Susan Pyne ${ }^{+}$ \\ Cell Biology Group and Pharmaceutical Analysis and Metabolomics Research Group, Strathclyde \\ Institute of Pharmacy and Biomedical Sciences, University of Strathclyde, 161 Cathedral Street, \\ Glasgow G4 ORE, UK \\ 'Department of Chemistry and Biochemistry, Queens College of the City University of New York, \\ Flushing, New York 11367-1597, USA \\ "The University of Illinois at Chicago Section of Pulmonary, Critical Care, Sleep, and Allergy, 909 \\ S. Wolcott Ave., Chicago, IL 60612, USA
}

\section{SUMMARY}

Two isoforms of sphingosine kinase, SK1 and SK2, catalyze the formation of the bioactive lipid sphingosine 1-phosphate (S1P) in mammalian cells. We have previously shown that treatment of androgen-sensitive $\mathrm{LNCaP}$ prostate cancer cells with a non-selective SK isoform inhibitor, 2- $(p-$ hydroxyanilino)- 4-( $p$-chlorophenyl)thiazole (SKi), induces the proteasomal degradation of SK1. This is concomitant with a significant increase in C22:0-ceramide and sphingosine levels and a reduction in S1P levels, resulting in the apoptosis of $\mathrm{LNCaP}$ cells. In contrast, we show here that a SK2-selective inhibitor, $(R)$-FTY720 methyl ether (ROME), increases sphingosine and decreases $\mathrm{S} 1 \mathrm{P}$ levels but has no effect on ceramide levels and does not induce apoptosis in LNCaP cells. We also show that several glycolytic metabolites and $(R)-S$-lactoylglutathione are increased upon treatment of $\mathrm{LNCaP}$ cells with $\mathrm{SKi}$, which induces the proteasomal degradation of c-Myc. These changes reflect an indirect antagonism of the Warburg effect. LNCaP cells also respond to SKi by diverting glucose 6-phosphate into the pentose phosphate pathway to provide NADPH, which serves as an antioxidant to counter an oxidative stress response. SKi also promotes the formation of a novel pro-apoptotic molecule called diadenosine $5^{\prime}, 5^{\prime \prime \prime}-P^{1}, P^{3}$-triphosphate (Ap3A), which binds to the tumor suppressor fragile histidine triad protein (FHIT). In contrast, the SK2-selective inhibitor, ROME, induces a reduction in some glycolytic metabolites and does not affect oxidative stress. We conclude that SK1 functions to increase the stability of c-Myc and suppresses Ap3A formation, which might maintain the Warburg effect and cell survival, while SK2 exhibits a nonoverlapping function.

\section{Keywords}

Sphingosine kinase; glycolysis; Warburg effect; oxidative stress; diadenosine triphosphate; cancer; proteasome; LNCaP metabolome

\footnotetext{
(c) 2012 Elsevier Inc. All rights reserved.

+To whom correspondence should be addressed (Tel: 441415482012; Fax: 441415522562; susan.pyne@strath.ac.uk).
}

Publisher's Disclaimer: This is a PDF file of an unedited manuscript that has been accepted for publication. As a service to our customers we are providing this early version of the manuscript. The manuscript will undergo copyediting, typesetting, and review of the resulting proof before it is published in its final citable form. Please note that during the production process errors may be discovered which could affect the content, and all legal disclaimers that apply to the journal pertain. 


\section{INTRODUCTION}

Sphingosine kinase is a lipid kinase that has two isoforms, SK1 and SK2, which are encoded by distinct genes and differ in their biochemical properties, subcellular localization, and function [1]. SK1 mRNA transcript and/or protein expression are increased in various human tumors [1]. These findings support the hypothesis that high SK1 expression in cancer cells confers positive selection to these cells. Indeed, siRNA knockdown of SK1 reduces proliferation of glioblastoma cells [2] and androgen-independent PC-3 prostate cancer cells [3]. In addition, large vascularized resistant tumors are formed when cancer cells overexpressing SK1 are injected or implanted into mice [1, 4]. SK1 is also a sensor that confers chemotherapeutic resistance, promoting the survival of cancer cells in the presence of certain anti-cancer agents [5].

We have previously reported that the treatment of cancer cells for $24-48 \mathrm{~h}$ with a nonselective SK isoform inhibitor, SKi (2-( $p$-hydroxyanilino)-4-( $p$-chlorophenyl)thiazole), activates the proteasome to remove SK1 from breast and prostate cancer cells $[5,6]$.

Ubiquitin-proteasomal degradation of SK1 occurs by a ceramide-dependent mechanism after an initial inhibition of SK activity [5]. This leads to a reduction in the intracellular S1P level and an elevation of C22:0-ceramide level, which is thought to induce apoptosis [5]. Importantly, the apoptotic effect is 'on-target' as it can be recapitulated by siRNA knockdown of SK1 in breast cancer cells [7]. The apoptotic effect induced after proteasomal degradation of SK1 is consistent with the loss of S1P, which is known to regulate apoptotic proteins, such as Bax and Bad [8].

Prostate cancer cells express two N-terminal variants of SK1 [5], termed SK1a and SK1b. SK1b has an $86 \mathrm{~N}$-terminal amino-acid extension compared with SK1a, and is also sometimes referred to as SK1c. The properties of the SK1b variant have not been well characterised yet its presence in cancer cells is important as it confers a cell survival advantage [5]. SK1b is very stable, being resistant to the protein synthesis inhibitor cycloheximide and siRNA knockdown in prostate cancer cells [5]. However, SK1b is sensitive to SK inhibitor-induced proteasomal degradation in androgen-sensitive prostate cancer cells [5,6]. Therefore, SK inhibitors represent an effective method for reducing the amount of this protein in these cells to facilitate meaningful study of its role in cancer biology.

There is emerging evidence for an important role of SK2 in cancer. This is exemplified by the finding that the siRNA knockdown of SK2 enhances doxorubicin-induced apoptosis of breast or colon cancer cells [9] and reduces cancer cell proliferation and migration/invasion [10]. However, there is also evidence that SK1 and SK2 have opposing actions [11]. Therefore, there is a need to develop isoform-selective inhibitors in order to better define the role of these enzymes in cancer cells. ( $R$ )-FTY720-OMe (ROME) is a specific, enantioselective, competitive (with sphingosine) inhibitor of SK2 [12]. Treatment of MCF-7 cells with ROME prevents actin enrichment into lamellipodia in response to S1P, suggesting that metastasis can be inhibited [12]. The $\mathrm{K}_{\mathrm{i}}$ values for inhibition of SK2 by ROME and a second SK2-specific inhibitor, ABC294640, are very similar (16.5 $\mu \mathrm{M}$ and $10.0 \mu \mathrm{M}$, respectively $[12,13])$.

A major phenotypic hallmark of cancer cells is their obligate need to convert glucose to lactate under aerobic conditions (the Warburg effect) to produce ATP required for cancer cell growth [14]. We hypothesized that indirect inhibition of the Warburg effect by targeting the SK isoforms might provide an approach for selectively attacking cancer cells that display 'addiction' to SK. Therefore, we decided to investigate the roles of SK1 and SK2 in regulating the metabolome of androgen-sensitive $\mathrm{LNCaP}$ prostate cancer cells in which we 
have previously extensively characterized the effect of SK inhibitors $[5,6,11]$. These studies have enabled determination of the roles of SK1 and SK2 in regulating the Warburg effect, thereby maintaining survival and immortality of cancer cells.

\section{EXPERIMENTAL PROCEDURES}

\section{Materials}

All general biochemicals were from Sigma (Poole, UK). RPMI 1640, OptiMEM, penicillinstreptomycin (10000 U/ml penicillin and $10000 \mu \mathrm{g} / \mathrm{ml}$ streptomycin), L-glutamine and Lipofectamine $2000^{\mathrm{TM}}$ were from Invitrogen (Paisley, UK). European fetal calf serum (EFCS) was purchased from Sera Laboratories (Haywards Heath, UK). SKi was from Merck Biosciences (Nottingham, UK). MG132 was from Enzo Life Sciences (Exeter, UK). ROME was synthesized as described previously [12]. Antibodies were obtained as follows: antiactin from Sigma (Poole, UK); anti-myc from Santa Cruz Biotechnology (Santa Cruz, CA), anti-ERK2 from BD Transduction Laboratories (Oxford, UK). Anti-SK1 antibody was a kind gift from Dr Andrea Huwiler (University of Berne, Switzerland). LNCaP cells were gifts from Professor Hing Leung (Beatson Institute, Glasgow). Myc-tagged SK2 plasmid construct was generated as described previously [16].

\section{Cell Culture}

Human androgen-sensitive LNCaP cells were maintained in RPMI 1640 medium supplemented with $10 \%$ EFCS, $100 \mathrm{U} / \mathrm{ml}$ penicillin, $100 \mu \mathrm{g} / \mathrm{ml}$ streptomycin and $1 \% \mathrm{~L}$ glutamine. All cells were maintained in a humidified atmosphere at $37^{\circ} \mathrm{C}$ with $5 \% \mathrm{CO}_{2}$. LNCaP cells were transiently transfected with a myc-tagged SK2-pcDNA4 plasmid construct using Lipofectamine $2000^{\mathrm{TM}}$ reagent according to the manufacture's instructions.

\section{Preparation of Whole Cell Extracts}

Cell extracts for SDS-PAGE and Western blot analysis were prepared by washing treated cells with $5 \mathrm{ml}$ of PBS and then re-suspending the cell pellets in whole cell lysis buffer [(137 $\mathrm{mM} \mathrm{NaCl}, 2.7 \mathrm{mM} \mathrm{KCl}, 1 \mathrm{mM} \mathrm{MgCl} 2,1 \mathrm{mM} \mathrm{CaCl} 2,1 \%$ v/v NP40, $10 \%$ v/v glycerol, 20 $\mathrm{mM}$ Tris) (pH 8.0) containing $0.2 \mathrm{mM}$ PMSF, $10 \mu \mathrm{g} / \mathrm{ml}$ leupeptin, $10 \mu \mathrm{g} / \mathrm{ml}$ aprotinin, 0.5 $\mathrm{mM} \mathrm{Na} \mathrm{VO}_{4}, 100 \mu \mathrm{M} \mathrm{NaF}$, and $10 \mathrm{mM} \beta$-glycerophosphate]. Samples were repeatedly $(\times$ 6) passed through a 23 -gauge needle using a syringe and rotated for $30 \mathrm{~min}$ at $4^{\circ} \mathrm{C}$ to allow for efficient lysis. Cell debris was pelleted by centrifugation at $22000 \times g$ for $10 \mathrm{~min}$ at $4{ }^{\circ} \mathrm{C}$, and the supernatant (whole cell extract) was collected. The protein content was measured using the Pierce BCA assay kit (Fisher Scientific, Loughborough, UK). For each sample, $10-20 \mu \mathrm{g}$ of protein was added to sample buffer [125 mM Tris, pH6.7, $0.5 \mathrm{mM} \mathrm{Na}_{4} \mathrm{P}_{2} \mathrm{O}_{7}$, $1.25 \mathrm{mM}$ EDTA, $0.5 \% \mathrm{w} / \mathrm{v}$ SDS containing $1.25 \% \mathrm{v} / \mathrm{v}$ glycerol, $0.06 \% \mathrm{w} / \mathrm{v}$ bromophenol blue, and $50 \mathrm{mM}$ dithiothreitol], and used for SDS-PAGE and western blotting using antimyc, anti-cyclin D1, anti-actin, anti-ERK2, and anti-PARP antibodies. For the detection of LC3 conversion (LC3-I to LC3-II) by immunoblotting for autophagy analysis, cells were washed with ice-cold PBS and resuspended in TNTE lysis buffer [20 mM Tris-HCl, 150 $\mathrm{mM} \mathrm{NaCl}, 5 \mathrm{mM}$ EDTA, 0.3\% Triton X-100, $50 \mu \mathrm{g} / \mathrm{ml} \mathrm{PMSF}$, Protease Inhibitor Cocktail; $\mathrm{pH}$ 7.5]. Samples were repeatedly $(\times 10)$ passed through a $0.24-\mathrm{mm}$ gauge needle and syringe and left for $5 \mathrm{~min}$ at $4{ }^{\circ} \mathrm{C}$ to allow for efficient lysis. After cell debris was pelleted by centrifugation at $22000 \times g$ for $10 \mathrm{~min}$ at $4{ }^{\circ} \mathrm{C}$, the supernatant was collected and the protein content was measured. For each sample, $80 \mu \mathrm{g}$ of protein was combined with sample buffer and subjected to SDS-PAGE and western blotting using anti-LC3 antibodies. 


\section{Proteasome Activity Assays}

Proteasome activity was measured in cells using a Proteasome Glo Chymotrypsin-Like Cellbased assay kit (Promega) as per the manufacturer's instructions.

\section{Analysis of Sphingoid Base 1-Phosphates and Ceramides}

Analyses of sphingoid base 1-phosphates, ceramides, and sphingoid bases were performed by electrospray ionization tandem mass spectrometry (ESI-LC/MS/MS) on an AB Sciex 5500 QTRAP hybrid triple quadrupole linear ion-trap mass spectrometers (Applied Biosystems, Foster City, CA) equipped with a TurboIonSpray ionization source interfaced with an automated Agilent 1200 series liquid chromatograph (Agilent Technologies, Wilmington, DE). S1P and dihydro-S1P (DHS1P) were analyzed as bis- $O$-acetylated derivatives with C17-S1P as the internal standard employing reverse-phase HPLC separation, negative ion ESI, and Multiple Reaction Monitoring (MRM) analysis as described in [15]. Ceramides were analyzed with C17-ceramide as an internal standard using reverse-phase HPLC separation, positive ion ESI, and MRM analysis as described in [16]. Briefly, resolution of sphingoid bases was achieved on a Discovery C18 column $(2.1 \times 50$ $\mathrm{mm}, 5 \mu \mathrm{m}$ particle size, Supelco, Bellefonte, PA) and a gradient from methanol/water/formic acid $(61: 38: 1, \mathrm{v} / \mathrm{v} / \mathrm{v})$ with $5 \mathrm{mM}$ ammonium formate methanol/acetonitrile/formic acid (39:60:1, v/v/v) with $5 \mathrm{mM}$ ammonium formate at a flow rate of $0.5 \mathrm{ml} / \mathrm{min}$. The MRM transitions employed for detection of sphingoid bases were as follows: $\mathrm{m} / z$ 286 $>268$ (C17Sph, internal standard); $\mathrm{m} / z 300>282$ (Sph); and $\mathrm{m} / z 302>284$ (DHSph).

\section{Isolation of Cell Extracts and Liquid Chromatography Mass Spectrometry}

$1 \times 10^{6}$ cells were plated in T- 25 cell culture flasks and grown until the cell number doubled $(48 \mathrm{~h})$ before being treated with SKi $(10 \mu \mathrm{M})$ or ROME $(10 \mu \mathrm{M})$ or vehicle for $24 \mathrm{~h}$. Cell extracts were prepared by washing the cells twice with PBS at $37^{\circ} \mathrm{C}$ before harvesting the cells into pre-cooled extraction solution $\left[\mathrm{MeOH} / \mathrm{MeCN} / \mathrm{H}_{2} \mathrm{O} 50: 30: 20\right]\left(1 \mathrm{ml}\right.$ per $2 \times 10^{6}$ cells). Cell lysates were mixed at $4^{\circ} \mathrm{C}$ at $1440 \mathrm{rpm}$ for $12 \mathrm{~min}$ before being centrifuged at $0^{\circ} \mathrm{C}$ at $13000 \mathrm{rpm}$ for $15 \mathrm{~min}$. The supernatants were collected and transferred into HPLC vials for loading into the LC-MS autosampler. The chromatographic conditions were as follows: A ZICpHILIC column $(150 \times 4.6 \mathrm{~mm} \times 5 \mu \mathrm{m})$ was eluted with a linear gradient over 30 min between $20 \mathrm{mM}\left(\mathrm{NH}_{4}\right)_{2} \mathrm{CO}_{3}(\mathrm{pH} 9.2) / \mathrm{MeCN}(20: 80)$ at $0 \mathrm{~min}$ and $20 \mathrm{mM}$ $\left(\mathrm{NH}_{4}\right)_{2} \mathrm{CO}_{3}$ (pH 9.2)/MeCN (20:80) at $30 \mathrm{~min}$ with a flow rate of $0.3 \mathrm{ml} / \mathrm{min}$, followed by washing with $20 \mathrm{mM}\left(\mathrm{NH}_{4}\right)_{2} \mathrm{CO}_{3}(\mathrm{pH}$ 9.2)/MeCN (95:5) for 5 min and then re-equilibration with the starting conditions for $10 \mathrm{~min}$. LC/MS was carried out by using an Accela HPLC pump coupled to an Exactive (Orbitrap) mass spectrometer from Thermo Fisher Scientific (Bremen, Germany). The spray voltage was $4.5 \mathrm{kV}$ for positive mode and $4.0 \mathrm{kV}$ for negative mode. The temperature of the ion transfer capillary was $275^{\circ} \mathrm{C}$ and sheath and auxiliary gas was 50 and 17 arbitrary units, respectively. The full scan range was 75 to 1200 $\mathrm{m} / \mathrm{z}$ for both positive and negative modes. The data were recorded using the Xcalibur 2.1.0 software package (Thermo Fisher Scientific). The signals of $83.0604 \mathrm{~m} / \mathrm{z}(2 \times A C N+H)$ and $91.0037 \mathrm{~m} / \mathrm{z}$ (2xformate-H) were selected as lock masses for the positive and negative modes, respectively, during each analytical run. Lactoylglutathione values were obtained from runs on a ZICHILC column under conditions described in [17].

\section{Data Extraction}

Data extraction was carried out by using Sieve 1.3. The ion chromatograms were pasted into an Excel macro written in house and the library was searched against a database of accurate masses for compounds in the Human Metabolome Data Base, KEGG, and Metlin. P values for two or more runs were combined using Fisher's method 


\section{RESULTS}

\section{Sphingosine Kinase Inhibitors}

We have used SKi, which inhibits both SK1 and SK2 activity [5], and ROME, which is a selective inhibitor of SK2 activity [12]. We characterized the effect of these SK inhibitors on androgen-sensitive LNCaP prostate cancer cells. These cells express two N-terminal variant isoforms of SK1; namely SK1a (GenBank number: NM_001142601), which is a 42.5-kDa protein, and SK1b (GenBank number: NM_182965), which is a 51-kDa protein identical to SK1a but has an 86 amino acid N-terminal extension. LNCaP cells also express SK2 [6]. Treatment of LNCaP prostate cancer cells with SKi $(10 \mu \mathrm{M}, 24 \mathrm{~h})$ reduced the expression of SK1a and SK1b [5]; Fig. 1A). We have previously shown that the SKi-induced degradation of SK1 is blocked by the proteasomal inhibitor, MG132 and the ceramide synthase inhibitor, fumonisin B1 [5]. The reduction of SK1a and SK1b expression is associated with the onset of apoptosis as assessed by the cleavage of the DNA repair enzyme, polyADP ribose polymerase (PARP) [5]; Fig. 1A). The ability of SKi to activate the proteasome (Fig. 1B) also results in the degradation of cyclin D1 ([5]; Fig. 1A). We show here that SKi also reduces the expression of the proto-oncogene, c-Myc (Fig. 1C), which is prevented by the proteasomal inhibitor MG132 (Fig. 1C). A similar reduction in c-Myc expression is observed in polyps of ApcMin/ ${ }^{-} S k 1^{-/}$mice [18], where both SK1a and SK1b are eliminated. SKi failed to modulate the expression of ectopically expressed SK2 in LNCaP cells (Fig. 1C), thereby demonstrating specificity for SK1. However, treatment of LNCaP cells with ROME (10 $\mu \mathrm{M}, 24 \mathrm{~h})$ eliminated ectopically expressed myc-tagged SK2 from LNCaP cells (Fig 1D). This is in common with similar findings in HEK 293 cells, where SK2 is removed via a mechanism that does not involve a proteasomal route of degradation [12]. In contrast with HEK 293 cells, ROME failed to induce apoptosis, as assessed by the lack of increased PARP cleavage relative to control cells and had no effect on c-Myc or cyclin D1 expression levels (Fig. 1E), consistent with its failure to activate the proteasome (Fig. 1B).

We found that SKi and ROME exert different effects on LNCaP autophagy. Thus, SKi (10 $\mu \mathrm{M}, 48 \mathrm{~h})$ inhibits autophagy whereas ROME (10 $\mu \mathrm{M}, 48 \mathrm{~h})$ stimulates autophagy, as reflected by the relative changes in the amounts of the non-lipidated inactive (LC3-I) and lipidated active forms (LC3-II) of LC3 (autophagy marker protein) (Fig. 1F). The reduced autophagic response as a consequence of SK1 inhibition/proteasomal degradation is consistent with previous findings that showed that nutrient starvation promotes autophagy via an SK1- dependent mechanism in MCF-7 cells [19] while the stimulatory effect of ROME on autophagy is similar to that observed with the SK2 inhibitor ABC 294640 [13]. We have previously shown that ROME has no effect on SK1 expression [12].

\section{Effect of Sphingosine Kinase Inhibitors on Sphingolipids}

We have also assessed the effect of ROME (10 $\mu \mathrm{M}, 24 \mathrm{~h})$ on sphingolipid levels, which were measured using ESI-LC/MS/MS. We have previously reported that SKi $(10 \mu \mathrm{M})$ has no effect on the intracellular levels of C14:0-, C16:0-, C18:1-, C18:0-, C20:0-, C24:1- and C26:1- ceramides, but substantially increased the C22:0-ceramide level and had a small effect on C24:0-ceramide [5, 20]. C26:0-, C28:0-, and C28:1-ceramides were undetectable $[5,20]$. In addition, the sphingosine level was increased and S1P level was decreased [5, 20]. In contrast, we show here that ROME has no significant effect on ceramide levels, but increased sphingosine levels and decreased S1P levels in LNCaP cells (Table 1). Taken together, these data support the conclusion that SKi acts through inhibition/proteasomal degradation of SK1, whereas ROME acts on SK2 in LNCaP cells. 


\section{Effects of SKi and ROME on the Metabolome and Oxidative Stress}

We next investigated the effect of SKi and ROME on the metabolome of LNCaP cells. The metabolites listed in Tables 2 and 3 were primarily identified according to their accurate masses which all had <2ppm mass deviation from the exact mass of the proposed metabolite. The metabolite database was used as a filter to exclude any other possible metabolites. This was done according to the metabolic standards initiative [21]. In order to differentiate between common isomers of metabolites, we matched the retention times (tr) with those of isomeric standards such as dihydroxyacetone phosphate and glyceraldehyde 3phosphate or 3- and 2-phosphoglycerate. Table 2A shows that treatment of LNCaP cells with SKi $(10 \mu \mathrm{M}, 24 \mathrm{~h})$ modulates the Warburg effect. This is indicated by the elevated levels of glycolytic metabolites (Table 2A) and increased levels of $(R)-S$-lactoylglutathione (Peak height 5790 +/- 55.3\% from SKi-treated cells, and absent from controls, $n=6$ ), which is formed from methylglyoxal (a highly reactive glycolytic byproduct that is apoptotic in prostate cancer cells [22]). These changes reflect accumulation of intermediates as a consequence of indirect antagonism of the Warburg effect. The glycolytic metabolites that are elevated by SKi treatment are fructose 1,6-bisphosphate, D-glyceraldehyde 3-phosphate, dihydroxyacetone phosphate, and 3-phosphoglycerate, suggesting that these metabolites accumulate due to inhibition of glycolytic pathway. Dihydroxyacetone phosphate is diverted to produce $(R)$-S-lactoyl-glutathione, which might occur as a consequence of its accumulation in response to antagonism of the Warburg effect. These data are the first report of a role for SK1 in regulating the Warburg effect in cancer cells.

The effect of SK inhibitors on the Warburg effect might be a consequence of the reduced expression of c-Myc (Fig. 1C), which is a master transcriptional regulator of flux through the glycolytic pathway [23, 24]. In addition, NADH levels are elevated in the SKi-treated cells, suggesting increased fatty acid oxidation. Treatment of cells with SKi also induces formation of diadenosine $5^{\prime}, 5^{\prime \prime \prime}-P^{1}, P^{3}$-triphosphate (Ap3A) (Table 2A).

LNCaP cells also respond to SKi by diverting glucose 6-phosphate into the pentose phosphate pathway in order to provide NADPH to counter oxidative stress responses. The glutathione (GSH) system uses NADPH to reduce the oxidized form, GSSG, to GSH. In this case, the protection afforded by NADPH toward oxidative stress is inadequate, since the levels of GSSG and pentose phosphate pathway intermediates (ribulose 5-phosphate and phosphogluconate) are increased and the NADPH level is reduced (Table 2A). Thus LNCaP cells appear to be overwhelmed by the oxidative stress, which may account for the subsequent apoptotic response.

The other major effects of SKi are on lipid metabolism, including marked changes in various acylcarnitines (Table 2A), which shuttle fatty acids in and out of the mitochondria. For instance, the levels of acetylcarnitine and 3-hydroxyhexanoylcarnitine are significantly elevated in LNCaP cells after treatment with SKi. Thus, LNCaP cells may be compromised in terms of synthesizing fatty acids/lipids in response to SKi. There is also a significant fall in free $\mathrm{CoA}$, suggesting that this might be a limiting factor. A function of acylcarnitines is to maintain homeostatic levels of free CoA [25]. The elevated levels of carnitines suggest that LNCaP cells might compensate for overload of the available CoA. Another source of acetyl CoA is lysine [26]; Table 2A shows that saccharopine, an intermediate of lysine degradation, is also elevated in SKi-treated LNCaP cells. This finding suggests an inability of this degradation pathway to function properly because of a lack of CoA.

SKi also increased the levels of 1- $O$-hexadecyl-2-lyso-phosphatidylcholine (Table 2A), a cell membranepermeable lipid that belongs to a class of alkyllysophospholipids known to induce apoptosis of cancer cells [27]. This lipid was not detected in ROME-treated cells. ROME had no significant effect on oxidative stress or the pentose phosphate pathway (Table 
2B). However, there was a small but significant effect on glycolysis, with glycolytic intermediates being depressed to about 50\% of the levels in the controls (Table 2B).

\section{Effect of N-Acetylcysteine on Metabolomic Changes in Response to SKi}

To examine the influence of oxidative stress on the metabolic changes in response to SKi, we pre-treated $\mathrm{LNCaP}$ cells with the reactive oxygen species scavenger $\mathrm{N}$-acetylcysteine (NAC). Table 3 shows that there was a reduced effect of SKi in NAC-treated cells. The increase in GSSG, NADH, saccharopine, hydroxyhexanoylcarnitine, acetylcarnitine, 1- $O$ hexadecyl-2-lyso-sn-glycero-3- phosphocholine and glycolytic metabolite levels in response to SKi was reduced in LNCaP cells pre-treated with NAC (Table 3). NAC also blunted the reduction in NADPH and CoA levels induced by SKi in LNCaP cells (Table 3).

\section{DISCUSSION}

We suggest that the SKi-induced proteasomal degradation of SK1 and the subsequent effect on ceramide, sphingosine, and S1P levels can be accounted for by a model in which the conversion of ceramide to sphingosine and S1P is regulated by ceramidase, SK1, and high S1P lyase activity; the latter enzyme catalyzes the irreversible degradation of S1P. High S1P lyase activity can function to maintain a low level of S1P in cells. Indeed, S1P levels are $>100$-fold lower than that of ceramide. Therefore, the concerted action of SK1 and S1P lyase represents a cellular turbine that drives the removal of apoptotic ceramide. Thus, the SKi-induced proteasomal degradation of SK1 would theoretically increase ceramide levels because the high flux is effectively blocked. This model is supported by the findings of Maceyka and colleagues, who demonstrated that over-expression of SK1 or siRNA knockdown of SK1 in HEK 293 cells resulted in marked changes of ceramide levels [28].

We found that the SK2-selective inhibitor ROME did not increase ceramide levels, thereby explaining its inability to induce apoptosis in LNCaP cells. However, ROME significantly increased the sphingosine and decreased the S1P level. The failure of ROME to increase ceramide levels suggests the absence of a cellular SK2-S1P lyase turbine that could potentially function to remove ceramide in LNCaP cells. Therefore, SK2 might function simply to dynamically regulate sphingosine-S1P cycling. This model is conducive to a second-messenger function for S1P as its concentration in cells can be potentially regulated by reciprocal regulation of SK2 and S1P phosphatase. A similar model for a role of SK2 in regulating S1P-sphingosine cycling and back conversion of sphingosine to ceramide, catalyzed by ceramide synthase, was proposed by Maceyka and colleagues, who demonstrated that over-expression of SK2 increased ceramide levels [28].

We have performed the first metabolomic analysis in prostate cancer cells in which SK1a and SK1b have been degraded by the proteasome in response to SKi. Our results demonstrate that SK1 inhibition/proteasomal degradation antagonizes the Warburg effect. This might be a consequence of the SKi-induced proteasomal degradation of c-Myc, thereby removing its oncogenic effect. c-Myc regulates the mRNA levels of the glucose transporter 1, phosphoglucose isomerase, phosphofructokinase, glyceraldehyde 3-phosphate dehydrogenase, phosphoglycerate kinase, and enolase, all of which are elevated in Rat1a fibroblasts and in murine livers over-expressing c-Myc [23]. c-Myc also up-regulates the expression of lactate dehydrogenase $\mathrm{A}$, which diverts pyruvate to lactate, and contributes to the Warburg effect [24]. Therefore, SK1 might function to limit proteasomal degradation of c-Myc to confer an efficient Warburg effect on cancer cells.

The prostate cancer cells also respond to SKi by diverting glucose 6-phosphate into the pentose phosphate pathway in order to provide anti-oxidant NADPH to counter oxidative stress responses. These findings are supported by the observation that shRNA knockdown of 
SK1 in carcinoma cells increases formation of ROS and sensitivity to doxorubicin-induced DNA damage [29]. Indeed, treatment of LNCaP cells with NAC reduced the effect of SKi on oxidized glutathione, NADPH, saccharopine, hydroxyhexanoylcarnitine, acetylcarnitine, and glycolytic metabolite levels. The effects of NAC are consistent with a model in which oxidative stress suppresses pyruvate kinase M2 (PKM2) activity, which is inactivated by oxidation of cysteine-358 [30]. Inhibition of PKM2 can cause accumulation of glycolytic metabolites and channelling of glucose into the pentose phosphate pathway.

Treatment of LNCaP cells increased the levels of Ap3A. The FHIT (fragile histidine triad protein) tumor suppressor gene product binds Ap3A to induce apoptosis. FHIT is also an Ap3A hydrolase, and this function may bear analogy with the GTPase activity of the Gprotein a subunit, which terminates the GPCR-G-protein activation cycle. Moreover, the intragenic alterations in the FRA3B/FHIT chromosome fragile site results in fragile FHIT allele loss early in cancer development [31]. Fhit knockout mice are also predisposed to tumor development, and Fhit gene therapy reduces tumor burden [32]. In addition, down regulation of FHIT protein is linked with extraprostatic extension and Gleason Score $>8$ in prostate cancer and advanced breast cancer. SNPs in Fhit are associated with aggressive disease and prostate cancer specific death [33]. Evidence strongly suggests the involvement of germ line variations of FHIT in prostate cancer risk [33]. Restoration of wild-type FHIT in 3p14.2-deficient human lung cancer cells also inhibits cell growth and induces apoptosis [34]. It is, therefore, significant that SKi induces an increase in the level of Ap3A in LNCaP prostate cancer cells as this might result in increased formation of Ap3A-FHIT complex that might induce apoptosis. The enzyme tryptophanyl-tRNA synthetase is responsible for catalyzing the formation of Ap3A from ATP, ADP, and tryptophan [35].

At the molecular level, the growth suppressive properties of FHIT have been linked to the up-regulation of the cell cycle regulator $\mathrm{p} 21^{\text {waf } 1}$, a potent inhibitor of cyclin-dependent kinases [36]. With respect to its apoptotic function, FHIT has also been shown to interact with ferridoxin reductase to produce ROS and to induce apoptosis of cancer cells [37]. Further investigation is required to establish whether the inhibition/proteasomal degradation of SK1 results in activation of tryptophanyl-tRNA synthetase-catalyzed formation of Ap3A or inhibition of FHIT Ap3A hydrolase activity.

In conclusion, our findings suggests that targeting SK1 might represent a novel strategy for antagonizing the Warburg effect without affecting normal cells that are not addicted to SK1 or the Warburg effect. The changes in NADPH and GSSG levels in response to SK1 inhibition suggest that prostate cancer cells fail to mitigate the swarm of ROS. SK1 might also limit ceramide-dependent ROS formation and thereby maintain the Warburg effect in cancer cells. Indeed, ceramide, which accumulates when SK1 activity is ablated in response to $\mathrm{SKi}$, induces pore formation in the mitochondrial membrane and leads to mitochondrial dysfunction [38], which results in ROS formation.

Our current study presents the first evidence for a functional link between SK1 and the cancer cell metabolome; a major hallmark of cancer. These findings provide an impetus for development of SK1 selective inhibitors, used to abrogate the Warburg effect in prostate cancer cells.

\section{Acknowledgments}

FT is a recipient of a Strathclyde University PhD scholarship. MAO is funded by a Saudi Government PhD scholarship. The work was funded, in part, by National Institutes of Health Grants HL-083187 to RB and 1P01HL098050 to EB. 


\section{ABBREVIATIONS}

$\begin{array}{ll}\text { Ap3A } & \text { diadenosine triphosphate } \\ \text { ERK } & \text { extracellular signal regulated kinase } \\ \text { FHIT } & \text { fragile histidine triad protein } \\ \text { GSSG } & \text { oxidized glutathione } \\ \text { GSH } & \text { reduced glutathione } \\ \text { LC3 } & \text { microtubule associated protein 1 light chain 3 } \\ \text { NAC } & \text { N-acetyl-cysteine } \\ \text { NADPH } & \text { nicotinamide dinucleotide phosphate } \\ \text { ND } & \text { not detected } \\ \text { PARP } & \text { polyADPribose polymerase } \\ \text { PBS } & \text { phosphate-buffered saline } \\ \text { ROS } & \text { reactive oxygen species } \\ \text { SDS-PAGE } & \text { sodium dodecyl sulfate polyacrylamide gel electrophoresis } \\ \text { SK1 } & \text { sphingosine kinase 1 } \\ \text { S1P } & \text { sphingosine 1-phosphate. }\end{array}$

\section{REFERENCES}

1. Pyne NJ, Pyne S. Nature Rev. Cancer. 2010; 10:489-503. [PubMed: 20555359]

2. Van Brocklyn JR, Jackson CA, Pearl DK, Kotur MS, Snyder PJ, Prior TW. J. Neuropathol. Exp. Neurol. 2005; 64:695-705. [PubMed: 16106218]

3. Akao Y, Banno Y, Nakagawa Y, Hasegawa N, Kim TJ, Murate T, Igarashi Y, Nozawa Y. Biochem. Biophys. Res. Commun. 2006; 342:1284-1290. [PubMed: 16516161]

4. Shirai K, Kaneshiro T, Wada M, Furuya H, Bielawski J, Hannun YA, Obeid LM, Ogretmen B, Kawamori T. Cancer Prev. Res. 2011; 4:454-462.

5. Loveridge C, Tonelli F, Leclercq T, Lim KG, Long S, Berdyshev E, Tate RJ, Natarajan V, Pitson SM, Pyne NJ, Pyne S S. J. Biol. Chem. 2010; 285:38841-38852. [PubMed: 20926375]

6. Tonelli F, Lim KG, Loveridge C, Long J, Pitson SM, Tigyi G, Bittman R, Pyne S, Pyne NJ. Cell. Signal. 2010; 22:1536-1542. [PubMed: 20570726]

7. Taha TA, Kitatani K, El-Alwani M, Bielawski J, Hannun YA, Obeid LM. FASEB J. 2006; 20:482484. [PubMed: 16507765]

8. Betito S, Cuvillier O. Biochem. Biophys. Res. Commun. 2006; 340:1273-1277. [PubMed: 16414356]

9. Sankala HM, Hait NC, Paugh SW, Shida D, Lépine S, Elmore LW, Dent P, Milstien S, Spiegel S. Cancer Res. 2007; 67:10466-10474. [PubMed: 17974990]

10. Gao P, Smith CD. Mol. Cancer Res. 2011; 9:1509-1519. [PubMed: 21896638]

11. Pyne S, Lee SC, Long J, Pyne NJ. Cell Signal. 2009; 21:14-21. [PubMed: 18768158]

12. Lim KG, Sun S, Bittman R, Pyne NJ, Pyne S. Cell. Signal. 2011; 23:1590-1595. [PubMed: 21620961]

13. French KJ, Zhuang Y, Maines LW, Gao P, Wang W, Beljanski V, Upson JJ, Green CL, Keller SN, Smith CD. J. Pharmacol. Exp. Ther. 2010; 333:129-139. [PubMed: 20061445]

14. Van de Heiden MG, Cantley LC, Thompson CB. Science. 2009; 324:1029-1033. [PubMed: 19460998]

15. Berdyshev EV, Gorshkova IA, Garcia JG, Natarajan V, Hubbard WC. Anal. Biochem. 2005; 339:129-136. [PubMed: 15766719] 
16. Berdyshev EV, Gorshkova IA, Usatyuk P, Zhao Y, Saatian B, Hubbard W, Natarajan V. Cell. Signal. 2006; 18:1779-1792. [PubMed: 16529909]

17. Zhang T, Creek DJ, Barrett MP, Blackburn G, Watson DG. Anal. Chem. 2012; 84:1994-2001. [PubMed: 22409530]

18. Kohno M, Momoi M, Oo ML, Paik JH, Lee YM, Venkataraman K, Ai Y, Ristimaki AP, Fyrst H, Sano H, Rosenberg D, Saba JD, Proia RL, Hla T. Mol. Cell Biol. 2006; 26:7211-7223. [PubMed: 16980623]

19. Lavieu G, Scarlatti F, Sala G, Carpentier S, Levade T, Ghidoni R, Botti J, Codogno P. J. Biol. Chem. 2006; 281:8518-8527. [PubMed: 16415355]

20. Lim KG, Tonelli F, Berdyshev EV, Gorshkova I, Leclercq T, Pitson SM, Bittman R, Pyne S, Pyne NJ. Int. J. Biochem. Cell Biol. 2012; 44:1457-1464. [PubMed: 22634604]

21. Griffin JL, Nicholls AW, Daykin CA, Heald S, Keun HC, Schuppe-Koistinen I, Griffiths JR, Cheng LL, Rocca-Serra P, Rubtsov DV, Robertson D. Metabolomics. 2007; 3:179-188.

22. Antognelli C, Mezzasoma L, Fettucciari K, Mearini E, Talesa VN. Prostate. 2012

23. Osthus RC, Shim H, Kim S, Li Q, Reddy R, Mukherjee M, Xu Y, Wonsey D, Lee LA, Dang CV. J. Biol. Chem. 2000; 275:21797-21800. [PubMed: 10823814]

24. Shim H, Dolde C, Lewis BC, Wu CS, Dang G, Jungmann RA, Dalla-Favera R, Dang CV. Proc. Natl. Acad. Sci. (USA). 1997; 94:6658-6663. [PubMed: 9192621]

25. Zammit VA, Ramsay RR, Bonomini M, Arduini A. Advanced Drug Delivery Reviews. 2009; 61:1353-1362. [PubMed: 19716391]

26. Benevenga NJ, Blemings KPJ. Nutrition. 2007; 137:1610S-1615S.

27. Van Der Luit AH, Budde M, Verheij M, Van Blitterswijk WJ. Biochem J. 2003; 374:747-753. [PubMed: 12837133]

28. Maceyka M, Sankala H, Hait NC, Le Stunff H, Liu H, Toman R, Collier C, Zhang M, Satin LS, Merrill AH Jr, Milstien S, Spiegel S. J. Biol. Chem. 2005; 280:37118-37129. [PubMed: 16118219]

29. Huwiler A, Kotelevets N, Xin C, Pastukhov O, Pfeilschifter J, Zangemeister-Wittke U. Br. J. Pharmacol. 2011; 162:532-543. [PubMed: 20883472]

30. Anastasiou D, Poulogiannis G, Asara JM, Boxer MB, Jiang JK, Shen M, Bellinger G, Sasaki AT, Locasale JW, Auld DS, Thomas CJ, Vander Heiden MG, Cantley LC. Science. 2011; 334:1278_ 1283. [PubMed: 22052977]

31. Ji L, Fang B, Yen N, Fong K, Minna JD, Roth JA. Cancer Res. 1999; 59:3333-3339. [PubMed: 10416589]

32. Pichiorri F, Palumbo T, Suh S-S, Okamura H, Trepasso F, Ishii H, Huebner K, Coce CM. Future Oncol. 2008; 4:815-824. [PubMed: 19086848]

33. Pomerantz MM, Werner L, Xie W, Regan MM, Lee GS, Sun T, Evan C, Petrozziello G, Nakabayashi M, Oh WK, Kantoff PW, Freedman ML. Cancer Prev. Res. 2011; 4:719-728.

34. Deng WG, Nishizaki M, Fang B, Roth JA, Ji L. Biochem. Biophys Res. Commun. 2007; 355:993999. [PubMed: 17328863]

35. Vartanian I, Prudovsky I, Suzuli H, Dal Pra I, Kisselev L. FEBS Lett. 1997; 415:160-162. [PubMed: 9350987]

36. Sard L, Accornero P, Tornielli S, Delia D, Bunone G, Campiglio M, Colombo MP, Gramegna M, Croce CM, Pierotti MA, Sozzi G. Proc. Natl. Acad. Sci. (USA). 1999; 96:8489-8492. [PubMed: 10411902]

37. Trapasso F, Pichiorri F, Gaspari M, Palumbo T, Aqeilan RI, Gaudio E, Okumura H, Iuliano R, Di Leva G, Fabbri M, Birk DE, Raso C, Green-Church K, Spagnoli LG, Venuta S, Huebner K, Croce CM. J. Biol. Chem. 2008; 283:13736-13744. [PubMed: 18319262]

38. Novgorodov SA, Szulc ZM, Luberto C, Jones JA, Bielawski J, Bielawska A, Hannun YA, Obeid LM. J. Biol. Chem. 2005; 280:16096-16105. [PubMed: 15722351] 


\section{Highlights}

Background: Sphingosine kinase 1 and 2 are implicated in cancer.

Results: Inhibition of sphingosine kinase 1, but not sphingosine kinase 2 results in indirect antagonism of the Warburg effect.

Conclusion: Sphingosine kinase 1 limits proteasomal degradation of c-Myc which might promote the Warburg effect.

Significance: Sphingosine kinase 1 inhibitors might kill cancer cells by abrogation of the Warburg effect. 
(A)
(B)

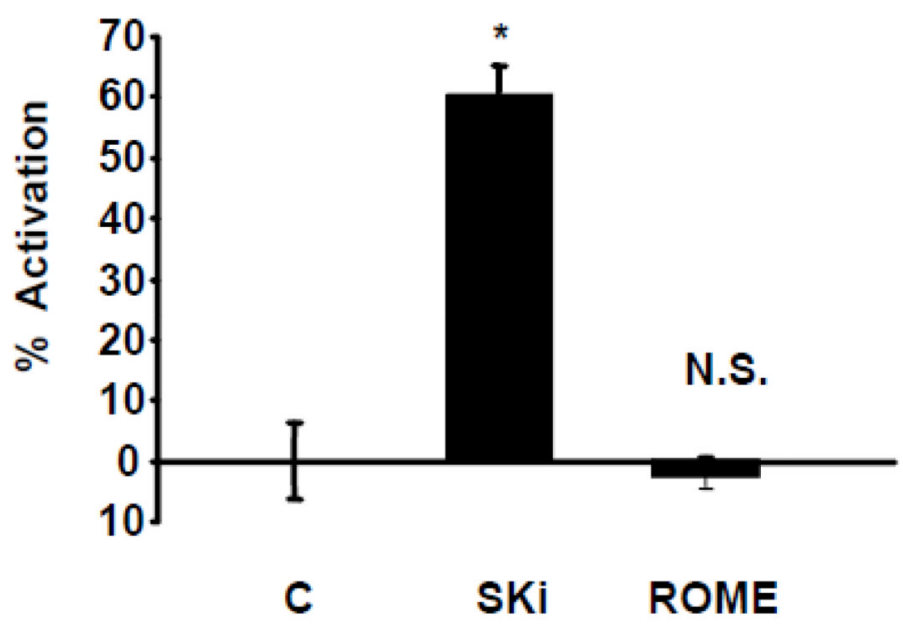


(C)
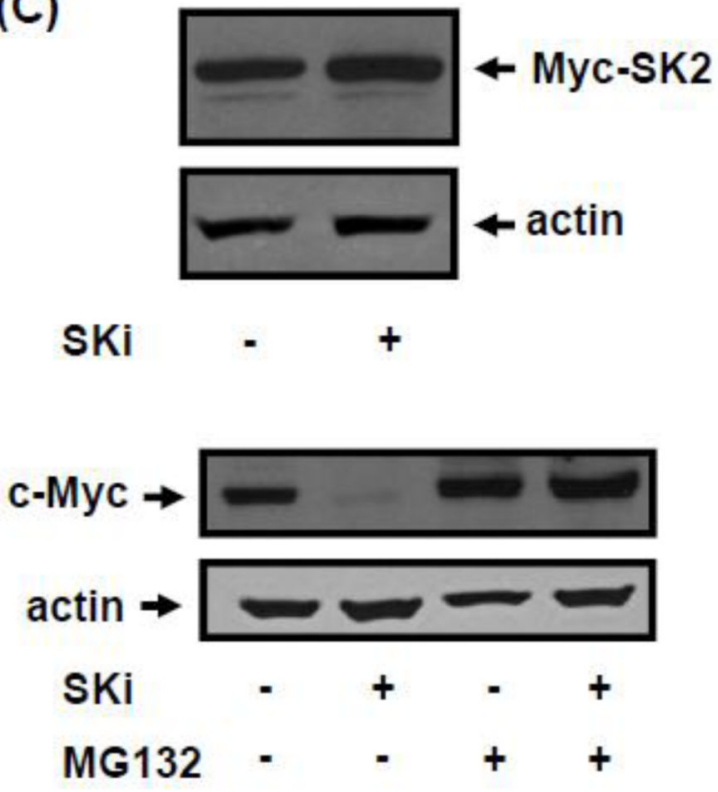

(D)
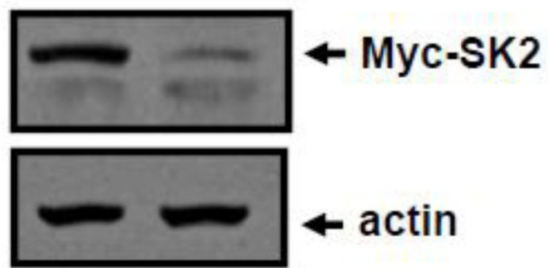

ROME
(E)

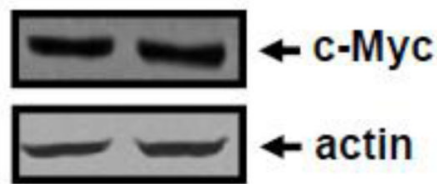

ROME

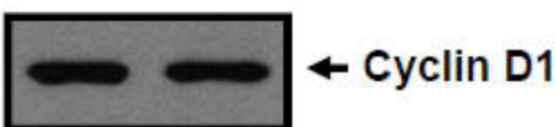

ROME
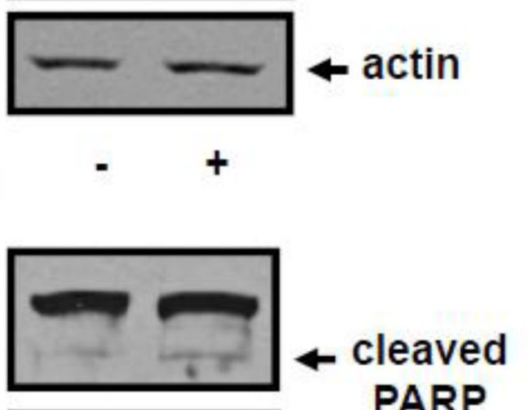

PARP

ROME

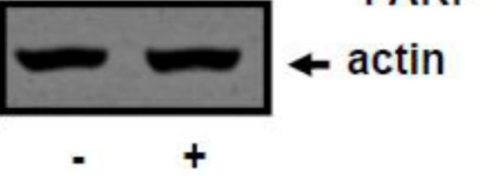

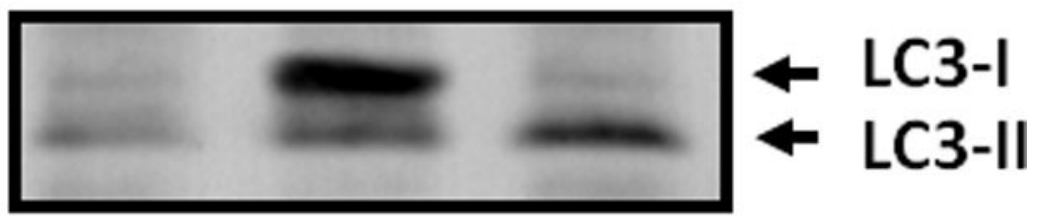
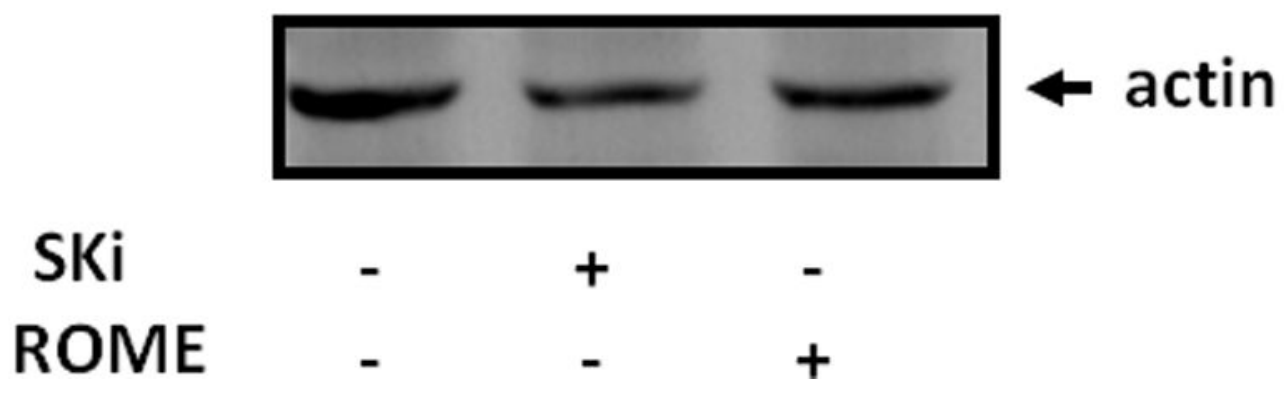

Figure 1. Effect of SK inhibitors on SK1, SK2, c-Myc, cyclin D1 expression, LC3 levels, and PARP cleavage in LNCaP cells

LNCaP cells were pre-treated with and without MG132 (10 $\mu \mathrm{M}, 30 \mathrm{~min})$ and then treated with SKi $(10 \mu \mathrm{M})$ or ROME $(10 \mu \mathrm{M})$ or with vehicle (DMSO, $0.1 \% \mathrm{v} / \mathrm{v})$ alone. The lysates 
were subjected to western blot analysis with specific antibodies or cells assayed for proteasomal activity. (A) Effect of SKi (24 h) on SK1a and SK1b expression, cyclin D1 levels and PARP cleavage; (B) Effect of SKi (24 h) and ROME (24 h) on proteasomal activity; (C) Effect of MG132 on the SKi (24 h) induced degradation of c-Myc. Also shown is the effect of SKi (24 h) on ectopically expressed Myc-SK2 levels; (D) Effect of ROME (24 h) on ectopically expressed Myc-tagged SK2 expression; (E) Effect of ROME (24 h) on c-Myc, cyclin D1 expression, and PARP cleavage; (F) Effect of SKi (48 h) or ROME (48 h) on LC3-I and LC3-II levels. Blots were stripped and re-probed with anti-ERK-2 or anti-actin antibodies to ensure comparable protein loading. Results are representative of at least 2-3 separate experiments. 


\section{Table 1}

Effect of ROME (10 $\mu \mathrm{M}, 24 \mathrm{~h})$ on ceramide, sphingosine, S1P, dihydrosphingosine, and dihydro-S1P levels in LNCaP cells.

\begin{tabular}{|c|c|c|}
\hline \multirow{2}{*}{ SPHINGOLIPID } & \multicolumn{2}{|c|}{ TREATMENT } \\
\cline { 2 - 3 } & C & ROMEl/nmol lipid P \\
\hline Cer 14:0 & $27 \pm 7$ & $26 \pm 1$ \\
\hline Cer 16:0 & $1985 \pm 305$ & $1935 \pm 101$ \\
\hline Cer 18:1 & $335 \pm 320$ & $576 \pm 53$ \\
\hline Cer 18:0 & $87 \pm 41$ & $62 \pm 7$ \\
\hline Cer 20:0 & $53 \pm 7$ & $68 \pm 6$ \\
\hline Cer 22:0 & $506 \pm 111$ & $460 \pm 26$ \\
\hline Cer 24:1 & $732 \pm 142$ & $796 \pm 30$ \\
\hline Cer 24:0 & $1401 \pm 435$ & $936 \pm 61$ \\
\hline Cer 26:1 & $79 \pm 13$ & $63 \pm 5$ \\
\hline Cer 26:0 & $25 \pm 17$ & $8 \pm 2$ \\
\hline Sph & $247 \pm 25$ & $411 \pm 56^{*}$ \\
\hline DHSph & $38 \pm 7$ & $65 \pm 11^{*}$ \\
\hline S1P & $8 \pm 39$ & $3.9 \pm 0.6^{*}$ \\
\hline
\end{tabular}

$P<0.05$ are presented for ROME-treated $(n=3)$ cells and the control (untreated, $n=6)$ cells. The data are the mean $+/-$ SD for each treatment.

$\mathrm{P}<0.05$ for ROME versus control. All other sphingolipids failed to show statistically significant changes in ROME-treated cells 


\section{Table 2}

Effect of (A) SKi (10 $\mu \mathrm{M}, 24 \mathrm{~h})$ or (B) ROME (10 $\mu \mathrm{M}, 24 \mathrm{~h})$ on metabolite levels in LNCaP cells. Results are expressed as the ratio $\mathrm{SKi} /$ control or $\mathrm{ROME} /$ control for each metabolite.

\begin{tabular}{|c|c|c|}
\hline \multicolumn{3}{|l|}{ Table 2A } \\
\hline & $\begin{array}{l}\text { Ratio } \\
\text { SKi:control }\end{array}$ & $P$ value $n=6$ \\
\hline \multicolumn{3}{|l|}{ Oxidative Stress } \\
\hline GSSG & 16.1 & $<0.001$ \\
\hline $\mathrm{NADP}^{+}$ & 4.0 & $<0.001$ \\
\hline NADPH & 0.20 & $<0.001$ \\
\hline Phosphogluconate & 4.3 & $<0.01$ \\
\hline Ribulose phosphate & 3.2 & $<0.001$ \\
\hline \multicolumn{3}{|l|}{ Glycolysis Krebs Cycle } \\
\hline Dihydroxyacetone phosphate & 11.5 & $<0.01$ \\
\hline Glyceraldehyde phosphate & 9.0 & $<0.01$ \\
\hline 3-phosphoglyceric acid & 2.2 & $<0.001$ \\
\hline Fructose 1, 6-bisphosphate & 18.2 & $<0.001$ \\
\hline NADH & 4.7 & $<0.001$ \\
\hline \multicolumn{3}{|l|}{ Fatty Acid Metabolism } \\
\hline Acetylcarnitine & 2.5 & $<0.001$ \\
\hline 3-Methylbutyryl carnitine & 0.21 & $<0.001$ \\
\hline Hydroxyhexanoyl carnitine & 2.4 & $<0.001$ \\
\hline Saccharopine & 3.6 & $<0.01$ \\
\hline $\mathrm{CoA}$ & 0.5 & $<0.001$ \\
\hline \multicolumn{3}{|l|}{ Apoptotic agents } \\
\hline 1-O-Hexadecyl-2-lyso-glycero-3-phosphorylcholine & 13.1 & $<0.001$ \\
\hline Diadenosine triphosphate & 2.2 & $<0.001$ \\
\hline
\end{tabular}

\begin{tabular}{|c|c|c|}
\hline & $\begin{array}{l}\text { Ratio } \\
\text { ROME:control }\end{array}$ & $P$ value $n=6$ \\
\hline \multicolumn{3}{|l|}{ Oxidative stress } \\
\hline GSSG & 0.88 & $>0.25$ \\
\hline $\mathrm{NADP}^{+}$ & 1.3 & $>0.25$ \\
\hline NADPH & 1.2 & $<0.001$ \\
\hline Ribulose phosphate & 0.74 & 0.15 \\
\hline \multicolumn{3}{|l|}{ Glycolysis Krebs Cycle } \\
\hline Dihydroxy acetone phosphate & 0.43 & $<0.01$ \\
\hline Glyceraldehyde phosphate & 0.47 & $<0.01$ \\
\hline 3-Phosphoglyceric acid & 0.79 & 0.2 \\
\hline Fructose 1,6-bisphosphate & 0.48 & $<0.01$ \\
\hline
\end{tabular}




\begin{tabular}{|c|c|c|}
\hline \multicolumn{3}{|l|}{ Table 2B } \\
\hline & $\begin{array}{l}\text { Ratio } \\
\text { ROME:control }\end{array}$ & $P$ value $n=6$ \\
\hline NADH & 0.91 & 0.15 \\
\hline \multicolumn{3}{|l|}{ Fatty Acid Metabolism } \\
\hline Acetylcarnitine & 1.1 & $>0.25$ \\
\hline 3-Methylbutyryl carnitine & 0.78 & $<0.05$ \\
\hline Saccharopine & 1.1 & $>0.25$ \\
\hline $\mathrm{CoA}$ & 0.89 & 0.25 \\
\hline \multicolumn{3}{|l|}{ Apoptotic agents } \\
\hline Diadenosine triphosphate & 0.93 & $>0.1$ \\
\hline
\end{tabular}

$\mathrm{P}$ values are presented for SKi or ROME versus control (experimental results from $\mathrm{n}=6$ cell samples for each treatment). Lactoylglutatione was not detected in control cells. 


\section{Table 3}

Effect of pre-treating LNCaP cells with NAC $(10 \mathrm{mM}, 1 \mathrm{~h})$ on the changes in metabolites in response to SKi (10 $\mu \mathrm{M}, 24 \mathrm{~h})$.

\begin{tabular}{|l|l|l|l|l|}
\hline & $\begin{array}{l}\text { Ratio } \\
\text { SKi:[SKi + } \\
\text { NAC] }\end{array}$ & P value n=3 & $\begin{array}{l}\text { Ratio } \\
\text { control: } \\
\text { [control + } \\
\text { NAC] }\end{array}$ & P value n=3 \\
\hline Oxidative stress & & & & \\
\hline GSSG & 4.4 & $<0.001$ & 0.64 & 0.34 \\
\hline NADP+ & 13.9 & $<0.005$ & ND & \\
\hline NADPH & 0.04 & $<0.001$ & 1.1 & 0.51 \\
\hline Ribulose phosphate & 0.41 & 0.054 & 1.1 & 0.7 \\
\hline Glycolysis Krebs Cycle & & & & \\
\hline Dihydroxyacetone phosphate & 2.1 & $<0.05$ & 0.81 & 0.022 \\
\hline Glyceraldehyde phosphate & 6.1 & $<0.05$ & ND & \\
\hline 3-Phosphoglyceric acid & 2.7 & $<0.005$ & 1.1 & 0.76 \\
\hline NADH & 2.7 & $<0.05$ & 1.4 & 0.19 \\
\hline Fatty Acid Metabolism & & & & \\
\hline Acetylcamitine & 2.4 & 0.066 & 0.96 & 0.87 \\
\hline Hydroxyhexanoyl camitine & 5.0 & $<0.001$ & 1.3 & 0.019 \\
\hline Saccharopine & 7.2 & $<0.05$ & 0.91 & 0.40 \\
\hline CoA & 0.65 & $<0.02$ & & \\
\hline Apoptotic agents & & & & \\
\hline 1-O-Hexadecyl-2-lyso-glycero-3-phosphorylcholine & 14.0 & $<0.005$ & 1.2 & 0.60 \\
\hline Diadenosine triphosphate & 1.1 & 0.53 & 0.77 & 0.15 \\
\hline & & & & \\
\hline
\end{tabular}

Results are expressed as the ratio SKi/[SKi + NAC] for each metabolite. P values are presented for SKi versus SKi + NAC (experimental results from $\mathrm{n}=3$ cell samples for each treatment). 